\title{
Continuing Social Constraints in Education Agency: The School Choices and Experiences of Middle- Class African American Families in Albany, NY
}

\author{
Paul Knudson \\ Methodist University, USA
}

DOI: http://dx.doi.org/10.18778/1733-8077.17.1.10

\section{Keywords:}

Urban Education;

Families and Schools;

Race; Social Class;

School Choice

\begin{abstract}
This paper explores the experiences of middle-class African American parents who have enrolled their children in a central-city public school district and the factors that inform and contribute to their school enrollment decisions. Data come from nineteen in-depth interviews with middle-class African American parents in Albany, New York. The paper uses the conceptual framework of empowerment and agency to explore and analyze the findings. Findings suggest that middle-class African American parents possess some measure of empowerment based on their human capital and positive childhood experiences in public schools. The latter denotes the salience of emotions in intergenerational education transmission. Parents' empowerment, however, does not fully extend to agency. Most parents' school choices have been structured and narrowed by racial segregation in residence and by the real and perceived racial exclusion in private school settings. Therefore, even for highly-educated, middle-income African Americans, anxieties over racial exclusion act as a strong social constraint on parents' community and school choices.
\end{abstract}

Paul Knudson is an Associate Professor and Chair of Sociology at Methodist University. His research focuses on urban and metropolitan affairs, urban schools and families, and race and ethnic relations. Previous articles have been published in City \& Community, State and Local Government
Review, Humanity E Society, American Journal of Qualitative Research, and others. A new project will focus on gentrification in Raleigh, NC.

email address: ptknudson80@gmail.com 


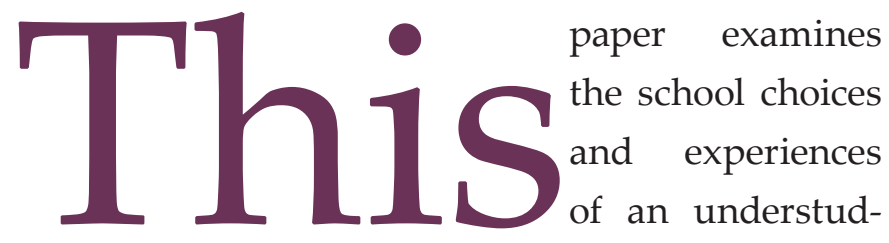

ied group: middle-class African American parents who have children enrolled in central-city public schools. The limited literature on middle-class African Americans and schools suggests they hold very high educational expectations for their children and value education to a greater extent than white parents of the same social class (Conley 1999; Bodovski 2010). In turn, studies suggest that black middle-class parents go to great lengths to secure the best schools for their children (Lareau 2003; Pattillo 2005; Montgomery 2006; Lacy 2007). Part of this process extends beyond academics and entails safeguarding their children from what they deem to be negative peer influences. Middle-class African American parents seek to endow their children with values and cultural norms that embody specific definitions of middle-class respectability and decorum (Pattillo-McCoy 1999; Hardaway and McLoyd 2009; Vincent et al. 2012a; 2012b).

The majority of the aforementioned studies have examined African American middle-class families in metropolitan areas with populations exceeding two million residents. In such places, despite continuing residential segregation, these African American families possess a limited but reasonable assortment of school options should they be skeptical about the quality of their neighborhood school. These include private schools, public magnet schools, charter schools, and suburban public schools. As such, those studies are not limited to families who have remained solely in public schools, particularly public schools in a central city. This study, in contrast, focuses only on middle-class parents who live in a central city and whose children are in public schools. This paper explores parents' motivations, constraints, and opportunities regarding school selection and the processes middle-class African American parents undertake to ensure their children have high quality and positive educational experiences in a small city of 100,000 people with fewer public school options. Because these parents have forgone suburban communities, this paper also briefly examines residential preferences. Finally, this paper explores some of the school experiences the participants' children have had in a central city district. Data for this study come from in-depth interviews with middle-class African American parents who have children enrolled in the City School District of Albany, NY.

This paper extends the literature on race and education in two ways. First, the findings further illuminate the specific mechanisms concerning how the racial/ethnic characteristics of schools and communities constrain and mediate the school preferences and school experiences of even relatively privileged African American families. Although the parents' relatively high class and educational statuses enabled their children to accrue social and academic benefits, this process did not fully offset racial disadvantage. In this sense, this study further distinguishes the sociological concepts of empowerment and agency (Pattillo 2015). Second, this paper extends the literature on intergenerational processes surrounding schools and education. Despite their children attending schools with an array of academic and behavioral problems, the participants' own positive experiences in public schools helped reassure parents that their children would acquire the necessary knowledge and skills to forge them into successful adults. This paper argues that parents' strong emotional connection to their own 
schooling as children is a part of intergenerational education transmission (Currie and Moretti 2003).

\section{The Contemporary Black Middle-Class and Education}

Relatively few studies have specifically focused on the educational choices and experiences of African American middle-class families in urban public schools and how they make sense of their circumstances. The majority of studies have centered on the experiences and constrained choices of the black poor (Kozol 1995; Grant 2009; Anyon 2014; Pattillo, DeLale-O'Connor, and Butts 2014; Rhodes and DeLuca 2014; Pattillo 2015). New research, however, has illuminated the black middle-class's experiences in K-12 schools. Concerned with status reproduction-like middle-class families from other backgrounds-they endeavor to find the best opportunities available for their children. For many, their neighborhood school is deemed deficient. For example, Montgomery (2006) noted the dynamic school choice patterns among black middle-class families in Los Angeles. Such families residing in low-income neighborhoods overwhelmingly bussed their children to public or private schools in middle-class neighborhoods. For families who resided in middle-class neighborhoods, one-half avoided their assigned schools and found schools situated in wealthier neighborhoods. Finally, despite their neighborhood schools holding the highest academic rankings, those who lived in affluent areas were the most likely of all groups to opt for private education.

Further research suggests that African American middle-class families utilize magnet and charter schools if faced with the prospect of their children having to attend low-ranking public schools
(Henig 1996; Carnoy et al. 2005; Bifulco, Ladd, and Ross 2009; Smrekar 2009a; Wells 2009; Haynes, Phillips, and Goldring 2010). For example, to avoid high-poverty public schools, magnets were popular among residents in Montgomery County, Maryland (Henig 1996) and in Nashville, Tennessee (Smrekar 2009b). Meanwhile, Lacy's (2007) research in Prince George's County, Maryland documents that even in near-affluent communities, many African American parents opt for magnets or private academies out of the sense that their neighborhood schools fail to provide an environment of academic excellence. This was analogous to the parents Pattillo-McCoy (1999) studied in Chicago who were attuned to college preparation and chose schools that had excellent track records of placing graduates in elite colleges.

In contrast, in Lacy's (2007) examination of near-affluent African American families residing in a predominately white, middle-class suburb in Virginia, parents tended to remain in their neighborhood public schools. This choice, however, did not mean that parents were unequivocally satisfied with their schools. Parents felt their children's teachers held lower expectations of black students and steered them towards less rigorous courses.

The ubiquity of low teacher expectations for students of color tends to be among the most consistent findings on studies on race and schools (Pattillo-McCoy 1999; Grant 2009; Vincent et al. 2012a; 2012b; Davis and Welcher 2013; Vincent et al.2013; Pattillo 2015). African American parents recognized that despite living in regions with first-class public schools, the racialized conceptions teachers held of their children forced them to proactively advocate for them (Lacy 2007). Such social dynamics have also been observed among middle-class 
black students in British schools. Parents learned their middle-class statuses failed to shield their children from negative stereotypes associated with the black poor. Race, in effect, eclipsed class (Gillborn et al. 2012; Vincent et al. 2012a; 2012b; Vincent et al. 2013).

In comparison to their white peers, the schools middle-class African American children attend are far more likely to consist of student bodies with populations at or below the poverty line (Pattillo-McCoy 1999; Davis and Welcher 2013). For example, nearly eighty percent of black middle-class households in Chicago in the 1990s lived within four blocks of census tracts in which more than one-third of the population lived in poverty (Pattillo-McCoy 1999). Because of protracted racial segregation that further concentrates black poverty (Friedman and Rosenbaum 2007; Freeman 2008), middle-class African Americans are far more likely than whites with similar incomes to live in high poverty neighborhoods.

Middle-class African American parents concerned with class reproduction take steps to insulate their children from negative peer influences they associate with lower-income African American students (Pattillo-McCoy 1999; Lacy 2007). In Lacy's research, parents limited their children's associations with working-class and low-income black children who lived in adjacent subdivisions. They feared their children would pick up bad habits including non-mainstream speech patterns. Similarly, parents in Pattillo-McCoy's study (1999) feared their children would engage in rebellious behaviors through interactions with teenagers with assumed gang affiliations or children from families that held a limited sense of middle-class values.
Despite having distinct histories and unique cultural frameworks, analogous findings were found among black middle-class families in Britain. Parents diligently worked to maintain and foster relationships with other professional black families who could reinforce positive examples of middle-class respectability. They simultaneously discouraged dress, vernacular, accents, and behaviors they deemed as "street" (Vincent et al. 2012a). Furthermore, parents enrolled their children in arts and music programs as opposed to merely athletics (Gillborn et al. 2012; Vincent et al. 2012a; 2012b; Vincent et al. 2013).

Notwithstanding these findings, gaps in the literature remain. Lacy's (2007) sample consisted of suburban, upper-middle-class families, many of whom enrolled their children in private schools. Relatedly, a large proportion of families in Pattillo-McCoy's (1999) study also chose private schools. Numerous parents in the British studies likewise opted for private academies (Gillborn et al. 2012; Vincent et al. 2012a; 2012b; Vincent et al. 2013). To bypass high poverty neighborhood schools, Henig (1996) and Smrekar (2009b) observed that middle-class African American parents in larger metropolitan areas chose public magnet schools. This study seeks to build on the existing literature by exploring the choices of African American middle-class parents in an urban district with limited options, including having only one public high school and no post-elementary-level magnet schools. Although charter and private high school options exist, the parents in this study have mostly refrained from these schools in the past, and only one currently had a child in a private school. Moreover, they have chosen to remain urban dwellers rather than moving to suburban areas in which the public schools have higher state exam scores and graduation rates (New York State Department of Education 2017). 


\section{Case, Methodology, and Sample}

This study was based in Albany, New York, a city of roughly 100,000 residents with a metropolitan population approaching 900,000 . Albany is approximately 57 percent white, 29 percent black/African American, and 14 percent "other," with Hispanics being the majority of that proportion (Bureau of the U.S. Census 2017). The public school population does not reflect that of the city. White students comprised just 20 percent of district enrollment for the 2015-2016 school year. At 50 percent, African American students are the largest group. Hispanic and Asian students comprise the fastest growing populations at 16 and 9 percent, respectively. Students at or below the poverty line and students who qualify for free or reduced-price meals stand at 29.4 percent and 60 percent of the student body, respectively (New York State Department of Education 2017). The district operates twelve elementary schools, three of which are magnet schools, three middle schools (no magnets), and one high school.

Substantial challenges face the district. During the time of data collection in 2015, three of Albany's public schools had been placed under state receivership because of continual subpar academic performance. When the New York State Department of Education places schools under receivership, it typically appoints the superintendent to take control of the school and usher in significant changes, including lengthening the school day, hiring additional teachers and support staff, and instituting new programs.

Unlike other studies of the black middle class that focus on families who live in low poverty, suburban areas (Lacy 2007), this study's setting of a central city is theoretically relevant. African Americans, even those who are middle-class, are far more likely than whites to live in neighborhoods with high levels of poverty (Sampson 2012). Indeed, for African Americans born between 1985 to 2000, 66 percent live in neighborhoods with poverty rates exceeding 20 percent. Moreover, 35 percent of African Americans in this age range live in neighborhoods with more than 30 percent of the population in poverty (Sharkey 2013). The setting of Albany, a city with a poverty rate of 25.6 percent (Bureau of the U.S. Census 2017), better reflects the environments that middle-class African American families actually live in (Capital District Regional Planning Commission 2015a).

The data in this study come from in-depth interviews with nineteen parents from eighteen households. The interviews occurred between December 2014 and October 2015. This paper is based on a larger project in which I interviewed forty-four parents from forty-two households. This subsample consists only of the African American participants from the larger sample. Mothers made up most of the parents interviewed. Fathers made up only two of the nineteen parents. I drew three participants from my social networks, ten through snowball methods, and recruited six participants at school board meetings and school open houses. The participants' names are pseudonyms. The names of the schools their children attended were altered except for Albany High School, which is the city's only public high school. I have no children in and no affiliations with the public schools in Albany, NY. Participants had to have more than a high school diploma and incomes between $\$ 47,700$ and $\$ 250,000$ to qualify for the study. The first figure represented 200 percent of the poverty line for a family of four in 2014 (U.S. Department of Health and Human Services 2014). Household incomes ranged from $\$ 48,500$ to $\$ 185,000$ with the median being just over $\$ 100,000$. 
Table 1. Social Characteristics of the Sample

\begin{tabular}{|l|l|}
\hline Characteristic & $\begin{array}{l}\text { No. of Households } \\
\text { and Percentage }\end{array}$ \\
\hline Median Household Income & $\$ 102,730$ \\
\hline$\$ 47,700$ to $\$ 60,000$ & $4(22.2)$ \\
\hline$\$ 60,001$ to $\$ 90,000$ & $6(33.3)$ \\
\hline$\$ 90,001$ to 150,000 & $6(33.3)$ \\
\hline$\$ 150,001$ and over & $2(11.1)$ \\
\hline $\begin{array}{l}\text { Education (highest degree } \\
\text { earned) }\end{array}$ & $10(58.8)$ \\
\hline Graduate degree & $6(29.4)$ \\
\hline Bachelor's degree & $2(11.8)$ \\
\hline Associate's degree & \\
\hline
\end{tabular}

Source: Self-elaboration.

The interviews were conducted by myself and three undergraduate students. I identify as a white male, while one student is an African American female, the second a white female, and the third a multiracial male. We interviewed participants in their homes, at coffee shops, and in my campus office. We recorded demographic information from each participant before beginning the formal interview. The interview questions were designed to create a free-flowing conversation and take about one hour. Meetings with participants, however, ranged from 45 minutes to two hours. All of the interviews were audio-recorded and transcribed verbatim. In addition to parent interviews, I also interviewed three members of the district's school board in order to better understand the important issues facing the district.
The qualitative method of in-depth interviews is an appropriate approach to the examination of the paper's research focus. Qualitative methods, including open-ended interview questions, allow participants to express their own feelings, emotions, and experiences surrounding the topic being explored (Hatch 2002). Participants were given broad latitude to discuss personal stories regarding education and the school choices and experiences pertaining to their children. We began the interviews by asking questions like, "How long have you lived in Albany?" "What led you to live in Albany?" "What has been the impression of the schools your children attend?" "What factors have influenced your school choices?" "How have your children's experiences been in school?" "What do you like or dislike about the schools your children attend?" "How have the teachers been in your children's schools?" These initial questions sparked a conversation which led to follow-up, probing, and clarifying questions.

This study uses a grounded theory approach in which a theory is established from the data themselves (Glaser and Straus 1967; Charmaz 2014). In contrast to testing rooted in a priori hypotheses and assumptions, grounded theorists attempt to understand reality from their participants' viewpoints, devising the questions and concepts to fit with what they encounter throughout the process of data collection. Derived from the inductive reading of the interview transcripts, after uploading each transcript in ATLAS.ti, I performed line by line manual coding in order to deeply engage with the data. My student assistants did not assist with the coding. The line by line coding resulted in numerous initial codes from the data fragments. These initial codes emerged from key words in contexts, striking or telling moments that provided insight, and common descriptions made by participants. Initial 
coding was performed after five transcribed interviews. After conducting and transcribing all of the interviews, I went back to the first transcriptions to reanalyze the data in order to evaluate whether or not codes that emerged in later interviews were also visible in the earlier ones.

After initial coding, I performed more focused coding to make sharper analytical sense of the participants' stories and statements. From this, I derived more abstract and analytical categories. These included participants' desire for inclusion and a sense of belonging in both their wider communities and in their children's schools, hopes that their children would experience exposure to the broader social world, aspirations for college, and apprehension regarding continual societal constraints, especially those regarding race.

From the analytical categories emerges the larger conceptual framework I use for this study. I did not begin the study using the framework. Rather, it materialized from the data. I use the theoretical framework of empowerment and agency to organize the findings and analysis of the paper. Concerning school choice, empowerment can be defined as the ability of parents to make informed decisions and realize their goals. For example, are parents able to escape or opt-out of mediocre or violent schools? Yet, empowerment goes beyond the mere execution of choice. Empowerment also entails agency (Pattillo 2015). Agency can be understood as "individuals' ability to act independently of social or structural constraints" (Campbell 2009:416). For example, are parents able to act without capitulation to or having to recognize larger institutional, societal, and economic forces, including institutionalized segregation? Agency better resembles "power over" a specific circumstance. Do these parents have power over or any real effect on the structural conditions of communities and schools? I argue that these middle-class African American parents possess more narrow forms of empowerment. Indeed, most parents have been able to successfully manage their children's educational experiences, enabling them to enjoy the best of what Albany's schools offer. Nonetheless, acquiring broader forms of empowerment, including agency, has been more elusive. These parents have felt compelled to remain in a below-average school system in a city with relatively high levels of poverty. This has resulted partially from a real and perceived sense of exclusion in other communities and spaces.

\section{Findings: Empowerment in Residence and Schools}

Despite the district's challenges the parents in this study all decided to remain in the city and overwhelmingly keep their children in public schools. In the first few sections of the findings, I focus on the empowerment these parents possessed in relation to residential location and school choice, including the empowerment that emerged through their own experiences in public schools as former students. In the latter part of the findings, however, I argue that despite the empowerment these middle-class African Americans do hold, agency, or "power over" a social condition is much harder to attain. To begin, however, I focus briefly on residential preferences in that residence largely determines which public schools are accessible to families.

Sixteen of the nineteen participants preferred the city over the suburbs. Only three desired to live outside of the city, but at this point, they had not felt compelled enough to move. Most enjoyed the conveniences and amenities associated with city life. 
This comment from Diane is representative of the broader sentiments of parents. Diane, an attorney with two children at Albany High explains, "I like the city neighborhoods...I like being able to walk to places. You can walk to the library, great restaurants, the park, and even the school."
Later in the paper, however, I discuss that city living was not purely a preference that attracted parents to the city, but that other factors were salient in dissuading them from living in outlying areas. Therefore, most parents' decision-making processes were complex and emotion-laden.

Table 2. Participant Household's Neighborhoods in Albany and Demographic Results by Neighborhood

\begin{tabular}{|c|c|c|c|c|c|c|}
\hline Neighborhood & $\begin{array}{l}\text { No. of } \\
\text { Households }\end{array}$ & Median HI & White & Black & Hispanic & Asian \\
\hline Olympus & 1 & 68,977 & 88.2 & 11.8 & - & - \\
\hline Pinewood & 1 & 95,733 & 84.2 & 9.6 & 2.6 & 0.9 \\
\hline Arcadia & 2 & 60,978 & 77 & 13.2 & 5.5 & 4.3 \\
\hline Irving Park & 1 & 41,875 & 73 & 15 & 3 & 6.7 \\
\hline Crescent & 1 & 71,333 & 71.1 & 16.5 & 5.6 & 5.3 \\
\hline Hollywood & 3 & 90,037 & 68.5 & 30.8 & - & - \\
\hline Mountain View & 2 & 53,713 & 55 & 33.5 & 2 & - \\
\hline Charleston & 2 & 32,750 & 48.1 & 21.3 & 11.3 & 17.8 \\
\hline Erie & 1 & 39,145 & 19.1 & 62.8 & 12.8 & 2.4 \\
\hline Beverly & 4 & 19,653 & 3.5 & 78.1 & 17.5 & - \\
\hline
\end{tabular}

Source: Bureau of the U.S. Census (2017).

Similarly, although complex factors regarding race, community and school inclusion, and personal histories within the public schools weighed heavily into the decisions parents made about schools, most parents also sought the highest quality school options available in the district, and they were quite successful at obtaining these. Like the families studied by Henig (1996) and Smrekar (2009a), many of the parents in this study sought magnet schools during the elementary years or specialized programs that operated within conventional public schools. Indeed, six of the eight families who resided in neighborhoods with median household incomes below $\$ 50,000$ did this. Compared to their assigned school, by seeking magnets and specialized programs, their children would attend schools with higher state test scores and a larger white student body. This pattern held for parents who lived in neighborhoods with incomes of $\$ 50,000$ or more in which six of ten sent their children to magnet schools. Their neighbor- 
hood elementary schools also had higher percentages of white students than the elementary schools in neighborhoods with incomes below $\$ 50,000$.

However, even for parents who chose magnet schools over their assigned schools, some had to engage in substantial advocacy and intervention on behalf of their children for them to obtain the type of education that met their needs and served their abilities. These parents, nonetheless, noted they were mostly successful in these efforts, which speaks of some measure of empowerment.

Table 3. Demographic Characteristic of Schools Attended by Participants' Children in comparison to Assigned Schools

\begin{tabular}{|c|c|c|c|c|}
\hline District School (Chosen) & \multicolumn{2}{|c|}{$\begin{array}{c}\text { Test Scores } \\
\text { Percent Proficient } \\
\text { Math English }\end{array}$} & $\begin{array}{l}\text { Percent Non- } \\
\text { White }\end{array}$ & $\begin{array}{c}\text { Percent } \\
\text { Free/Reduced } \\
\text { Lunch }\end{array}$ \\
\hline Albany High School & 10 & 54 & 80 & 55 \\
\hline \multicolumn{5}{|l|}{ Middle Schools } \\
\hline Lincoln & 14 & 29 & 75 & 57 \\
\hline Fordham & 13 & 22 & 82 & 61 \\
\hline
\end{tabular}

Elementary/Magnets

\begin{tabular}{|l|l|l|l|l|}
\hline Hillgrove & 42 & 48 & 43 & 27 \\
\hline Clayton & 20 & 19 & 83 & 48
\end{tabular}

Elementary/Neighborhood

\begin{tabular}{|c|c|c|c|c|}
\hline Providence & 38 & 36 & 50 & 40 \\
\hline Brookline & 22 & 23 & 62 & 52 \\
\hline
\end{tabular}

Maple Ridge* 15

$16 \quad 75$

District School (Assigned-Avoided)

\begin{tabular}{|c|c|c|c|c|}
\hline Prospect & 11 & 9 & 94 & 78 \\
\hline Ten Broeck & 7 & 8 & 96 & 80 \\
\hline Kendall & 10 & 16 & 94 & 79 \\
\hline
\end{tabular}

Source: New York State Department of Education (2017).

*Housed the language immersion program. 
Victoria is representative of the families who lived in neighborhoods with incomes below $\$ 50,000$ and avoided their assigned school. Victoria, an attorney, has two sons and a daughter. One of her sons is in middle school while the other is in high school. Her daughter attends a magnet elementary school. Although Victoria earns a high income, she lives in an impoverished neighborhood near downtown because she inherited a home there. She speaks of her daughter's assigned school, Prospect, as being unacceptable.

It just doesn't seem to be up to the standard that any school should be. The school itself, my daughter took singing lessons there. And they would meet there, and the school itself is in disarray, the kids seemed to be. I feel like it focuses a lot more on discipline than actual learning. So, no, I wouldn't have sent my kids there.

In addition to having lower state test scores, Prospect is overwhelmingly African American, with less racial diversity than the magnet school, Hillgrove, she chose for her daughter. All of her children, in fact, have gone through Hillgrove Magnet. She speaks highly of the school which operates on a lottery system.

I absolutely love it...We also realized the teachers were great, that academically [the kids] were doing well, so we were just very, very happy with it. So, once [my first son] went through, we sent our [younger] son who is fourteen, and then my daughter also came in as a sibling, because they have sibling preference. So, I just love it. I've had no complaints academically. They know us. They know my daughter. They seem to genuinely care about the students.

Victoria admits that she did scant research on schools. That task largely went to her ex-husband, the children's father. She notes, "He initiated everything because he did his research about it. He knows a lot of details, and so I just followed through with getting them into Hillgrove."

Wade and Kayla live in a working-class neighborhood, work in local government, and have two daughters who also currently attend Hillgrove. Like Victoria, they were not impressed with their neighborhood school, Brookline, and applied for Hillgrove. They were unable to get into Hillgrove initially. Kayla explains, "we signed up for Brookline because, like I said, we didn't get into the program at Hillgrove. We were in line like everyone else." The following year, however, they were able to enroll at Hillgrove. Then through sibling priority, both of their girls, Grace and Emma, gained entrance. Even though Wade and Kayla had sought out Hillgrove, the school disappointed them until they intervened with teachers and staff. When asked about their impressions of Hillgrove, Kayla and Wade replied:

Kayla: Generally good but mixed...Both our girls test above grade level...So the challenge was making sure the teachers were challenging them-not just giving them more work.

Wade: More work is not the point.

K: Grace had a fabulous kindergarten experience, but first and second grade, we weren't real...

W: I was horrified at first.

K: We were very upset in first grade. As I went to the open house-the regular teacher wasn't there-but a sub was...I told them, "You know, [our daughter] has been upset, she's, you know, because she's bored. What can you do to challenge her?"And [the teacher] says, "Well, we don't really see what you're saying. Once she starts finishing every reading in class, then I give her more to do." And I was like, "I don't think 
it works that way." Then I waited and talked to the Gen Ed teacher, and I still wasn't happy. But, [the teacher] did get her some books in their library. Interviewer: So, you want, it would be nice for more challenging readings?

K: And math. She scored really high in math.

W: She's one to two years ahead of grade level.

K: So, she's always loved it, very bright in math and reading, but math is her strength and enjoyment, and so my frustration was that she was still sitting through lessons that, things that she could pick up in a day.

I: So, the main thing at Hillgrove was just the lack of rigor?

K: With some of the teachers. Our younger daughter, Emma, she was reading Harry Potter because Grace was reading too, but Emma's teacher didn't believe us. But, we got her teacher to agree to sit down with Emma to see if she really could read Harry Potter, and she's like, "Yeah, she can read it, and she's understanding it."

K: So, she did great. She would pair up with another girl in her class that was at the same speed as Emma, and [the teacher] would give us some projects based around the books they were reading instead of the general books everybody else was reading.

In contrast to the trend of parents leaving Albany once their children reached school age (Correia 2015), Sandra and her husband recently had done the opposite and moved from suburban Colonie to the city. They have four children, three of whom were in elementary school at the time of the interview.

\section{I: What led you to move to Albany from Colonie?}

Sandra: Well, we have our own business in Albany, and we just, I honestly just wanted to be able to serve the community...So, I, my husband and I thought a lot about it and talked a lot about it and we decided to move here, and we have a lot of friends here, a lot of people who are in the community and have been rooting for us to move.

I: As far as the schools, were the schools you chose the ones you had wanted?

S: Yes, actually, out of the public schools in Albany those were my choices. Those, well, my son originally...he's a sixth-grader, and he goes to Hillgrove. He had started at Providence, but we moved him to Hillgrove, and it wound up being a very good experience for him so far. The girls are still at Providence. I: Why did you move him to Hillgrove?

S: There are different things. I think there needs to be more awareness of the kids. They don't really know where my kids are right now academically and things like that. And so that's the big issue. For example, I have two girls there; so my daughters are in third and first. My first grader is an advanced student that can read at about the same level as where her sister is. So, I really wanted to make sure she was challenged...but, at this point, no one really, it doesn't feel like they recognize...I don't want to be the parent-"My kid this, my kid that"-I wanted [the teachers] to just naturally kind of grasp what she's got and what she knows. But, after we've brought this up, I've seen that kind of shift. It's getting better.

Overall, families with children at the elementary level were successful in securing slots in the city's most desirable schools, which, in most cases, were the magnets. Still, some parents were not that happy with the schools until they intervened. Their dissatisfaction was tied to the lack of academic rigor of some of their children's classes. They felt highly of their children and demanded that teachers accommodate and better cultivate their children's talents. Sandra noted she did not want to be one of those parents who constantly expected special 
attention for their children, yet "fostering the love of reading" in her daughters was very important. The findings explored here support previous research (Crozier, Reay, and James 2011), which suggests that middle-class parents think very highly of their children and feel that they deserve the best of what schools offer.

\section{Parental Choices and Empowerment in the Post-Elementary Years}

Even with 100,000 residents, Albany has only one public high school and three public middle schools. There are no magnet schools at these levels. What the district does offer, however, are honors courses in middle school and Advanced Placement (AP) and International Baccalaureate (IB) coursework in high school. Parents overwhelmingly sought these programs and were quite satisfied with them. Although the AP and IB programs do not require an entrance exam and in theory are open to all children, the district places gatekeepers around their enrollment. The district recommends that students speak with their current teacher about the programs, an instructor who teaches courses in honors, AP or IB, and their school counselor. Parents are also encouraged to do all three things. Teachers and school staff subsequently decide if a student is prepared to handle the program (City School District of Albany 2017). All three of these "requirements" necessitate good communication skills, as well as confidence on the part of the student. Parents must also be involved, have the proper information, and meet with teachers and staff. The entire process, therefore, can potentially exclude students from households with limited parental guidance or awareness surrounding specific educational opportunities, and indeed, substantial academic segregation exists after the elementary level in Albany's schools (Interview with Albany City School District Board Member 2015).

These limitations, however, did not affect the parents in this study who possessed the know-how to obtain the best programs and classes for their children. This, however, did not mean it was an easy or automatic process for all parents. Some had to intervene in order for their children to be placed in advanced classes or at least classrooms with better teachers. Furthermore, one parent noted her immense effort required to obtain the support that her daughter, as a high-functioning special education student, needed in order to be successful in the honors-level classes.

Morgan, a state government worker with three children, discusses her son's experiences at Lincoln Middle School. Morgan has been successful in advocating for her son to be in all honors-level classes.

I: What's been your experience with your kids at Lincoln?

M: Oh, I love Lincoln.

I: What are some of the things you like about it?

M: Well...if there's something I don't like, they kind of compromise. Like, right now, [my son] has got all honors classes except one class, the math class, but that's changing. I don't understand with a 99 average how's that? And [the teacher's] reason was that, 'Well, he's a very smart kid, but I think that with all the other classes..." So, I said, "Well, whose decision is that? Wouldn't that be my decision?"...So, after my reasoning, voicing my opinions, and my statement... the teacher changed him into advanced algebra.

Carla, who works in journalism, has a son in middle school. Although she supports the district, she 
notes that it only works if parents are heavily involved and advocate for their children. Cole, her son, has been at Lincoln and was struggling until Carla intervened.

Cole is stressed about fights. He's smart, but he's shy, quiet. He needs individual attention. His grades were starting to slip; not bad, but not great either. But, I would go into Lincoln to meet with Cole's counselor and they said, "Oh, he's great" and that's it. Like, they're not on top of it. But, as an involved, vocal, parent, I made it give Cole the best that it could. So, it's a matter of, you know, if you get a good counselor. I had to go in and get him into the class with the good math teacher. We were able to get him an excellent art teacher that took to him and loved him...He became more engaged. So, I think Lincoln is only as good as it services the individual. As a whole, no, it's not good. But, it really can do wonders for someone, you know, but I think you really have to fight for it.

Finally, Monica has had a very similar experience as Carla with the city schools. Monica and her husband both work in law, but she recently quit her job to provide more attention to their younger daughter who has special needs. They had explored private schools, but found the education to be better in Albany's public schools as long as children got their needs met and entered into the honors/advanced programs. Monica explains:

M: I'm a unique parent. I have two daughters who are very different learners. And our daughter who is at Lincoln is in special education. If I was not dedicating a lot of hours, a lot of time, and a lot of research, my daughter would get a subpar education. But, I am a very big advocate, because I'm educated, because I take the time to learn my daughter's doing okay, with all of the support. But, I have to fight for everything I get...Our younger daughter has a chronic medical condition...Suffice to say, it's progressive. It's really important that she get the support that is legally entitled to her. She has a oneon-one para-professional who's fantastic...She is getting resource room time. And she gets that for reading, writing, and math...Teachers are wonderful, but they're not used to working as a team, and when you have an IEP, and it needs to be followed, and it requires a team approach, that's a problem for the school.

I: So, you've had to continuously advocate then, and it's a constant thing?

M: But, I get results. It's one reason I'm not working outside the home, because this takes up so much time. I have to learn how to read studies; I have to learn everything. So, because the district will not tell you; the district will not provide. They don't volunteer anything. So, I have to constantly be vigilant.

I: And your daughter's classes then, it is kind of some special classes....and some where she's mixed with others?

M: She is actually an honors student, and she takes honors classes. So, she doesn't fit the mold of what a special ed student is. She's severely dyslexic...She gets resource room time twice a day, but she's in honors classes and she's doing well, but she has support.

Monica and her husband explored private schools for their oldest daughter (the non-special needs daughter), but they did not come away impressed.

My older daughter is super accomplished. She would do well anywhere she went, but we did consider private school for her. You know, we were looking at Middleton Academy, but they are so regimented with their curriculum, and we weren't that impressed... My daughter didn't want to go; she wanted to go to 
Albany High...At Albany High as a ninth-grader, she is taking AP World History, AP Chemistry, AP Chinese. You cannot get that at Middleton.

On the whole, the parents in this study were quite successful in leveraging their power to make the public schools work for their children. For some, this resulted in being placed into honors programs, switching classrooms in order to be taught by better teachers, and acquiring the educational services their children needed. Parents noted that Albany public schools were relatively good as long as parents were heavily involved in directing attention and resources to their children. Relatedly, of all the parents who had children in middle or high school, only one did not have their child in any honors or an honors-type program (AP and IB). This parent, Josie, an attorney, explained that her son was not at the level of an honors student and, therefore, placed him in a private school so that he could receive the attention he needed. She notes, “We didn't think our oldest son would focus enough to stay and do what he needed to do. He'll get more structure at St. Mary's." The instances like Josie's illustrate a measure of efficacy and empowerment. Overall, whereas a substantial percentage of parents in Pattillo-McCoy's study (1999) on middle-class African American families utilized private schools, parents in this study with concerns about academic quality were largely assuaged by academic segregation (in the form of honors, AP, and IB) at the classroom level and by successfully directing school resources to their children.

\section{Intergenerational Education Transmission and Empowerment}

Although most parents noted that magnet schools, specialized programs, honors-level classes, and their successful advocacy for their children kept them in the district, their own positive experiences and outcomes as students in urban public schools also played a role in influencing their views on schools. Their personal histories assisted in creating intergenerational expectations that their children would excel in public schools. Moreover, three parents had actually attended Albany's public schools. These experiential factors endowed greater confidence that their children would do well within the district despite its array of problems. This endowment of confidence can also be understood as a component of the empowerment these parents possessed. One such parent was Morgan. Her legacy as an alumna of the district informs her outlook on her children's education in the city's schools.

I graduated from Albany High School, and I was in my top, top of the class. I can tell you the principal had an open-door policy, and so did Gerald Jennings as the assistant principal ${ }^{1}$...They, the guidance counselors, have open-door policy, and they will call you, you know, with whatever's going on...Albany High also allowed you to be who you are. It's one of the schools that I remember that you could be pregnant. I remember in Guilderland High School, that was like a no-no back in the days. But, at Albany High, if you were pregnant, you still were able to go to school. In suburbia, you're shunned. But, in general, Albany High, they want to be known as the best, and they keep working at it. There's so much pressure on them to do better-from the state, the mayor, all of that, and so my kids will be fine there.

Kari had a similar, positive experience in the city's school district.

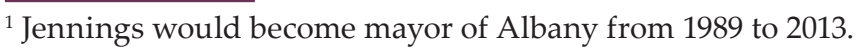


I know everything about it because I grew up in the projects, and the only thing about it that was different for my sister and I is that in fourth grade the school district had this program for academically-talented students, and I was in that. So, fourth through eighth grade, they tracked us in this program. I remember that it exposed me to a lot of things that I would've never been exposed to had I been in the average classes...The honors kids were a very mixed group-like half the class were white and half the class were black. So, those became our friends. So, we had birthday parties; they'd invite us. So, we'd go to South Main-nice houses-and I was like, “Wow, backyards! Fathers!” And my dad wasn't around, so I was like, wow, maybe I can...maybe my kids can have a father...So yes, my daughter is going to Albany High.

Even for parents who had not gone through the city's public schools, their own positive experience with public education influenced their school decisions. Verona grew up in a public school system in the South and excelled, as did a large part of her extended family. When asked what influenced her views towards public education, she responded with accounts of her own experiences and those of her relatives.

I went to integrated schools. Kids who were a year or two older went to segregated schools and the same schools that my mother went to and her siblings went to. And we knew that they were not getting what they needed, but there was a community built around their school. Then integration occurred, and so the public school became for everybody. I really think I went through what I would probably call a public school that was a great, great college-prep type school...That's where [my views] come from.
Verona's discussion on the school experiences of relatives and other community members that predated integration aligns with the literature on African American community schools. Prior to federally-mandated desegregation, faced with outright exclusion in white schools, many African American communities organized their own community-based schools (Stulberg 2004; Grant 2009). Most were parent-led. Despite the lack of financial resources and state support, these all-black schools offered African American children a sense of pride, group history, and cultural awareness that strengthened their self-esteem. Verona continues her discussion:

I had grandparents, great grandparents that were not-I think my grandfather went as far as the sixth grade. But, they had eleven children, and out of the eleven, I have four military uncles. One was a fourstar general. I have another who was a former Vice Provost of [a major university]. So, everyone-and my cousins were lawyers and dentists and educatorsand so I grew up with that. And my family started with people who were railroad men, butlers like Douglas Fairbanks. But, basically, the message was, "go and get yours"; "get your degree"; "school is important"; and I believe in that. And it happened to be the public education system I was in; it worked for me and worked for my family.

The quotes from Verona, Kari, and Morgan underscore the importance of intergenerational transmission of educational values that influenced the schools they selected for their own children. The parents in this study largely had positive experiences in public schools. Their confidence in public schools is salient given that African Americans have never fully trusted the public sector to meet their children's academic needs (Stulberg 2004). Public education for black communities has often come 
with low teacher expectations, teacher labeling, substandard facilities, racially-motivated stereotypes, unfair disciplinary actions, and a lack of safe environments (Grant 2009).

Although additional factors were important in determining school selection, participants' own positive experiences within public schools provided a strong emotional pull towards public education. The specific public schools they attended all provided them with important opportunities and resources that affected their life chances. For Kari, her time in public schools granted her access to new forms of social, as well as cultural capital. Social capital can be defined as social network assets that foster assistance and reciprocity and create opportunities to enhance outcomes for an individual, group, or community (Coleman 1988). Cultural capital consists of "knowledges" and credentials that are highly valued in society, particularly by people who have greater levels of authority and influence. Individuals with higher levels of cultural capital possess more power (Bourdieu 1984; Bourdieu and Passeron 1990). Overall, parents' own positive experiences in public schools endowed them with a sense of efficacy and confidence that their children would also excel in public schools.

\section{Lack of Agency}

\section{Anxieties Concerning Suburban Communities and Suburban Schools}

The paper now turns to explore how issues surrounding race continue to limit parents' empowerment, illustrating a lack of agency, or the ability for these families "to act independently of larger social and structural constraints" (Campbell 2009:416). Lack of agency was reflected in the narrow range of communities and schools in which most parents felt comfortable. Although not a formal form of exclusion, the participants could not act independently of the social or structural constraints concerning communities and schools. They had to deliberate upon racial integration, inclusion, and acceptance, and felt compelled to avoid spaces that lacked these qualities. For example, although most participants enjoyed city life, they also noted factors that dissuaded them from living in Albany's predominantly white suburbs. Most had never lived in suburbs and felt they could not move there because of their nearly all-white population as shown in Table 4 . They sensed that in comparison to their relatively integrated city neighborhoods, they would stick out and be treated unfairly in suburban areas.

Table 4. Demographic Characteristics of Municipalities in Albany County

\begin{tabular}{|c|c|c|c|c|}
\hline Municipality-City & \$ Median HH Income & Poverty Rate & \% White & H.S. Graduation Rate (4 years) \\
\hline Albany & 42,335 & 25.6 & 57.01 & 60 \\
\hline Municipality-Suburb & & & & \\
\hline Bethlehem & 92,708 & 4.5 & 91.9 & 94 \\
\hline Guilderland & 76,955 & 5.6 & 86.2 & 93 \\
\hline Colonie & 72,135 & 6.6 & 85.2 & 91 \\
\hline
\end{tabular}

Source: Capital District Regional Planning Commission (2015b). 
Cindy works as a business manager at a local firm. She and her ex-husband have two children, one in middle school and the other in elementary school. She explained that she would not feel comfortable in Albany's suburbs. Their city neighborhood is by comparison 73 percent white.

When we first started looking for a home, it was a struggle because my husband-even though he was African American-he grew up military and had a very different African American experience. And he wanted to consider Bethlehem [a popular suburb], and I just, I didn't want to be the only ones [who were black there]. I was always, you know, urban. I grew up urban. So, this was what I was comfortable with.

Nick and Geneva are state government employees and have two children in elementary school. The couple said they would be wary of moving to an actual suburb. Their city neighborhood is 71.1 percent white.

We were actually talking about this issue this past weekend. And we were like, in Bethlehem the kids would probably have to deal with some race issues there, you know, even though they have a lighter complexion. But, with their hair and all the stereotypes, they'd probably have their own set of issues. Somebody gets upset with them or jealous of them enough where they'll call them a name just to bring them down...We don't feel like our children would be treated equal to everyone else, including by the teachers. It's unfair. It's unfortunate, but it's the way life is.

Kari and her husband have three children, own a small consulting business, and live in a neighborhood that is 68.5 percent white. She said they neither considered the suburbs when they bought their house a few years ago, nor would they now. She de- scribes the first time she had to travel to a meeting in an outlying area of Albany.

Oh, Selkirk, Ravena, Niskayuna...oh, down there in the woods like that, oh, man! So, it's so funny because [my business partner and I] had all these reservations about going to these different areas for meetings. It's so funny because she said, "Oh, I'll bring my husband with me," and I'm saying, "Oh, me too!" [laughing]. Because I'm going to a rural area, and I'm not comfortable. All I can think about is the South back in the sixties. It's scary. And to other black folk, I'd say, in Albany, you'd be fine, out in the burbs, I don't know.

This unease of suburbia extended to parents who had for a time actually lived in the suburbs, but moved back into the city. They too noted that they felt more comfortable in the city. One of these parents was Kelsey, a registered nurse, and mother of two. Kelsey and her children lived in suburban Saratoga County several years ago, but moved back to Albany when her youngest son was in Pre-K.

When we were outside Saratoga, [my son] was really one of a few children of color. Even when he was in Pre-K. And I grew up like that, and I'm very sensitive to that, and I don't want them to feel...I want them to see people around them that look like them. I don't mean for it to be all one race. I think that's weird too, but it should be diverse....And another thing, both his teacher and the principal at that time, they would always say these strange things when I came in. They meant to be friendly, I think, like saying, "Oh, it's so nice we have a black family here," but it felt weird.

The residential preferences of the parents reflect research suggesting that African Americans prefer racially-integrated neighborhoods (Krysan et al. 2009; 
Swaroop and Krysan 2011). The parents also underscore some of the thought and emotional processes they undertake when determining the place in which they wish to reside. Most families felt the city was a better option, a place that provided a stronger sense of belonging. Yet, forgoing a suburban home meant not having access to some of the high- est-ranking school districts in the entire state. Test scores and graduation rates in every adjacent suburban district far exceeded that of Albany's schools, particularly in Bethlehem (New York State Department of Education 2017). A dynamic of the limited agency is revealed in the narrow parameters of suitable community options for these parents.

Table 5. Characteristics of Neighboring Suburban School Districts

\begin{tabular}{|c|c|c|c|c|}
\hline School (Municipality) & \multicolumn{2}{|c|}{$\begin{array}{c}\text { Test Scores } \\
\text { Percent Proficient } \\
\text { Math English }\end{array}$} & \multirow[t]{2}{*}{$\begin{array}{c}\text { Percent } \\
\text { Non- } \\
\text { White }\end{array}$} & \multirow[t]{2}{*}{$\begin{array}{c}\text { Percent } \\
\text { Free/Reduced } \\
\text { Lunch }\end{array}$} \\
\hline & & & & \\
\hline Bethlehem Central (Bethlehem) & 40 & 91 & 11 & 9 \\
\hline Guilderland (Guilderland) & 51 & 91 & 19 & 13 \\
\hline Shaker (Colonie) & 45 & 88 & 25 & 14 \\
\hline \multicolumn{5}{|l|}{ Middle Schools } \\
\hline Central (Bethlehem) & 66 & 65 & 11 & 8 \\
\hline Farnsworth (Guilderland) & 56 & 46 & 21 & 16 \\
\hline Shaker (Colonie) & 67 & 60 & 26 & 15 \\
\hline \multicolumn{5}{|l|}{ Elementary Schools } \\
\hline Elsmere (Bethlehem) & 72 & 72 & 7 & 13 \\
\hline Glenmont (Bethlehem) & 51 & 59 & 12 & 6 \\
\hline Guilderland (Guilderland) & 55 & 62 & 33 & 17 \\
\hline Blue Creek (Colonie) & 52 & 38 & 32 & 21 \\
\hline Loudonville (Colonie) & 79 & 65 & 20 & 5 \\
\hline Southgate (Colonie) & 66 & 62 & 26 & 17 \\
\hline Latham Ridge (Colonie) & 64 & 39 & 28 & 21 \\
\hline Boght Hills (Colonie) & 69 & 53 & 32 & 15 \\
\hline Fort's Ferry (Colonie) & 57 & 48 & 30 & 18 \\
\hline
\end{tabular}

Source: New York State Education Department (2017). 


\section{A Sense of Exclusion in Private Schools}

The lack of belonging parents said they would feel (or felt) in suburban communities and suburban public schools, for many, extended to private schools. Nearly all of the parents believed that the area's best private schools were either too socially isolating for their children or racially segregated, with these being intertwined. The following quotes highlight this. Cindy and her ex-husband have stayed away from private schools, but they have discussed the topic. She first touches on her daughter's middle school, Lincoln, which has a majority of low-income and African American, before discussing private schools.

Lincoln doesn't allow them to view the fact that they're predominately African American and poor to define them...Black people exist. Hispanics exist. They do not, not exist. So, to raise my children in a world that's not representative of that isn't fair. We're not doing that...The private schools are a bubble. I did not want my kid to be one of three [African American students]. My ex-husband was always the only [African American], and I think it did horrible things to him...We had a teacher [at Lincoln] who was always the only one, and when they are the only one, they grow up different. Something happens to them.

Diane and her husband have two children, both at Albany High. Over the years they researched the area's private schools because they felt they needed to be aware of the existing options and opportunities. Despite this, their children have remained in the city's public schools.

I: And so, what was the key factor in remaining in the public schools?
D: I think it was the diversity...all kinds of racial, socio-economic classes, the whole thing, and just the exposure to that. It was just an important part of their learning process and who they are...That to me was really important, and we have had good experiences with the teachers...But, that's...diversity is really important...We thought about the Catholic girl's high school for our daughter, but there's little diversity. She wouldn't even get out of the car if we visited [laughing].

Finally, Brooke and her husband have three children, one at each level of school. Brooke is a manager at a state agency, while her husband works in software. Their two older children had for a time been in private schools in Albany, but they ultimately returned to the public system.

I: So [two of your children] were in private schools. What led you to go back to public schools?

B: I saw when my son and daughter were at Tryon Academy...so again it's about balance. You get a great curriculum, content, but there's something else that you lose [at a private school]. If you're not of the same ilk of the class, you've got that whole thing to deal with. It's harder to make friendships because you're not in the same circuit. I think [the Catholic school] is probably a little bit more diverse, but I don't think they're as academically strong as Tryon. And I found with my son, finishing there, it was a challenge for him to maintain friendships, to feel like he was welcome. Like he was the only black player on the football team. It just wasn't right.

Wells and Crain (1997) examined African American families who participated in an inter-district transfer program that bussed thousands of mostly poor, African American students from St. Louis into predominantly white, middle-class suburban 
schools. Although transfer students benefited from more rigorous academic environments and by various forms of capital associated with wealthier, white communities, they felt a sense of alienation from the tacit cultural knowledge shared between white teachers and their suburban white students, as well as social isolation. Urban students were, of course, bussed back to the city at the end of the school day. They, in turn, found it difficult to build friendships in the absence of peer interaction during evenings and weekends.

On the surface, it may appear that these African American middle-class parents possessed many options, including suburban residence, high quality suburban public schools, and private schools. The appearance of options, however, obscured the real structural constraints felt by these families. They were reticent of residing in the heavily white suburbs around Albany and sending their children to the public schools in those communities. In addition, their selection of Albany's public schools was influenced by their apprehension towards the city's private schools. What both of these processes have in common is a continuing level of discomfort, even among comparably privileged African American parents, for overwhelmingly white spaces. It was less that formal barriers existed to prevent families from accessing these spaces, but rather social and symbolic barriers. Parents needed both themselves and their children to feel a sense of welcome and belonging in the schools and in the broader community. Indeed, unlike findings of Wells and Crain (1997) and Lacy (2007), the parents in this study, although not entirely satisfied with the teachers, did not mention that their children's instructors made them feel different or separate due to their race. This was the benefit of being in urban public schools.
Ultimately, for these parents, community and school choice is a complex social-emotional process. Entangled with other, more "objective" factors like test scores are parents' own social, emotional, and non-material concerns regarding race, inclusion, and their personal histories in public schools. This supports previous research suggesting that emotion and rationality are mutually dependent elements in how human beings construct and undertake important life decisions (Gould 2009).

\section{Racially-Segregated Academic Programs}

Finally, although parents found much to like in Albany's public schools, including specific academic programs and relative diversity in comparison to alternative sites, the legacy of racial disempowerment and educational exclusion continued to structure social interactions and peer networks in Albany's schools, particularly at the high school level. This reveals a lack of agency. Albany High's strong AP and IB programs, which separate higher-performing students from others in their cohort, also contribute to racial segregation. Honors classes at the middle school level are also segregated, but at more moderated levels (Interview with City School District of Albany Board Member 2015). White students disproportionately populated the advanced classes taken by the children of the parents in this study. Thus, the irony is that whereas parents avoided suburban and private schools due to a lack of racial diversity and inclusion, in the honors, AP and IB classes, African American students were in the minority (Interview with City School District of Albany Board Member 2015). This led to social consequences. Most parents noted that the majority of their children's classmates and school friends were actually white. Shauna describes her son's experiences. 
In his honors classes, I would say he has one friend who is black, and dozens who are white [laughs]. And because we live in our neighborhood, he has a lot of friends from around our neighborhood who, one's mom just got out of jail, various sets of circumstances. So, he's not in classes with most of the people in our neighborhood, but he knows them...but most of his closer friends are white kids, like ninety-five percent.

Diane also mentions that her children's friends from school are mainly white. At the same time, however, her children would find it peculiar to be in an all-white environment.

Probably the majority of my kids' friends are white, but I think they're doing okay because they do see other black kids in the non-IB classes, like music. It's okay; it's just how Albany High is designed. I wish it could be different, but I don't know how you get actual academic integration because then the middle class would leave. I mean, I know many peoplepeople tell me this all the time.

Kari's oldest daughter attends Lincoln Middle School and is in honors. She, however, is concerned that her daughter is struggling to find her way in school, partially as a result of her status as a middle-class African American student in a school that is disproportionately black and low-income. Unlike Shauna and Diane's children who are enrolled in AP and IB classes at Albany High, Kari's daughter in middle school has not been able to compensate for the lack of African American friends with white friendships. Kari hopes this will change in high school.

I: How has your daughter's experience been at Lincoln?
K: It started off positive, but then it's gotten more and more negative. She texted me yesterday and said, they're doing Regents review and she doesn't have a partner. No one wants to partner with her... The thing about it is she's not black enough [laughs]. So, she said, "Well, mom, why do I talk like this?" The black kids are like, "Why do you talk like that?" And then she's like, "What? Like what?" She's not like, urban enough. You know?

Prior research suggests that African American college students who come from racially integrated community backgrounds tend to do better socially and academically, but are often unfamiliar with urban black culture and fail to connect with low-income, black college students (Torres and Massey 2012). Based on the experiences of some of the families in this study, even middle-class African American students who reside in urban centers and have wide exposure to lower-income African Americans can still feel relatively isolated from their lower-income peers and certain aspects of this culture. Still, the parents in this study did not appear to be overly concerned that their children's school friendships generally consisted of white students. Neighborhood venues or extra-curricular activities balanced some of their networks with respect to race. Their children were also mostly excelling academically. Nonetheless, even in a relatively diverse school district in which a plurality of students are African American, some students lacked strong peer/friendship networks with other African American students because of academic segregation and social class differences.

Another complex dynamic is that whereas parents' own children benefited academically from classroom segregation, some like Diane held mixed feelings regarding this. But, her sense that 
changing Albany High's structure would alienate the city's middle-income families and lead them to leave is documented in the literature (Stillman 2012). Therefore, funding of "gifted and talented" programs is often preserved (Stillman 2012). In Albany, middle-class parents relied on the honors, $\mathrm{AP}$, and IB programs and did not want to see those compromised even if their children were among the few students of color in these classes.

\section{Discussion and Conclusion}

This study explored the factors that influenced parents to remain in a central city and enroll their children in public schools. Their choices are a result of both their empowerment, but also their limited agency. Most parents enjoyed Albany and city living, but because most did not feel welcome in either suburban areas or in the city's private schools, these families felt their options were essentially limited to urban living and urban public schools. Because of this, parents were determined to make the city's public schools work for their children. This included enrolling them in the more desirable magnet schools at the elementary level, and ensuring they would be in honors, $\mathrm{AP}$, and IB programs in the post-elementary years. The AP and IB programs were especially relevant given that Albany only has one public high school. This is a unique characteristic with respect to the community context of this study. Accordingly, many parents engaged in substantial advocacy work and intervention so that their children would be instructed by the best teachers, tasked with more challenging projects, and receive the best services available in the district. To that end, unlike the low-income parents examined by Pattillo (2015), these parents possessed some level of empowerment. They used their human capital to successfully manage the school system to make it serve their children.

Nonetheless, these middle-class African American parents could not fully enjoy the levels of agency held by their white counterparts. Agency can be understood as the ability to operate independently of broader structural constraints and larger institutional forces. The city's best schools still do not measure up academically to public schools in the suburbs. For example, even the city's best public elementary school as measured by test scores, Hillgrove, had lower test scores and higher rates of students living in poverty than the lowest ranking suburban elementary school (Blue Creek).

Yet, Albany's suburbs gave them a sense of unease and exclusion. That Albany's suburbs are predominantly white is a product of the legacy of exclusion on the basis of race. Racist policies and practices by the federal government, commercial banks, and real estate actors (Massey and Denton 1993; Friedman and Rosenbaum 2007) helped create a stark racial divide between cities and suburbs. Today, these discriminatory practices continue in different forms (Kuebler 2012). These institutional barriers regarding race, residence, and non-inclusion were too much for most of these parents to overcome.

The perceptions of the families in this study relate to those of Wells and Crain (1997) in that parents feared their children would feel a sense of racial exclusion and isolation if they attended either private or suburban schools. Moreover, in Brooke's children's experience in private schools, this indeed occurred. Therefore, the findings from this study suggest that both a sense of social isolation and exclusion, as well as actual experiences of such can occur not just for low-income African Amer- 
ican students who are bussed to mainly white, suburban public schools (Wells and Crain 1997), but also among highly educated, middle-class African American families.

This study's findings support previous studies that examine the parental transmission of educational values and outcomes (Currie and Moretti 2003; Spielauer 2004; Patacchini and Zenou 2007). Yet, this study also furthers the literature by suggesting that intergenerational education transmission can be a highly emotional process related to identity construction (Gould 2009). Parents identified strongly with aspects of their schooling that led them to become the people they were today. A handful noted how public education lifted them out of impoverished families. Public education was related to social and racial integration, as well as upward class mobility. These powerful abstract and emotive factors affected their school choice decisions.

Limitations of this study include the small sample size of the parents interviewed and that data were only collected from parents. The similarity of certain findings in this study to previous literature on black middle-class families, however, suggests some level of generalizability. A larger sample, nonetheless, could have included African American parents who left the city or enrolled more of their children in private schools. This would help isolate the factors that are unique to the parents in this study. Furthermore, follow-up interviews with parents, for example, two years after the initial interviews could provide important information regarding school outcomes and add to the validity of the findings. Interviews and other data collection methods with the students themselves would also provide yet another empirical layer to the study.
Although parents with children at the high school level-with the exception of one child-were able to enroll them in advanced programs, they had few African American peers there. Despite the diversity of the district, parents could not overcome considerable classroom academic segregation, a product and legacy of unequal structural conditions between African Americans and whites. Does the absence of having high performing peers of one's own social background harm students? Previous research suggests that high performing African American students are able to successfully incorporate black identity with academic achievement (Horvat and Lewis 2003). Most parents in my study noted that while their children did not have many African American peers in their advanced classes, extracurriculars enabled socialization with black peers. Yet, future research is necessary to better understand these processes. New studies could collect data from students themselves and compare students who are involved in extracurriculars and/or outside community groups with those who are not. Many charter schools and private schools offer fewer extracurriculars in athletics, music, and theater (Ravitch 2014). These dynamics could impact students. Budget cuts due to the economic mismanagement of the COVID-19 pandemic could also upend school budgets and place both extracurriculars and honors programs at risk (Cohen 2020). These forces have hit communities of color the hardest (Cohen 2020). There is going to be a need for substantial new research on the educational consequences of the pandemic-induced crisis.

Finally, the academic segregation of the children of these parents experienced points to the continuing reproduction of educational stratification (Collins 2009). Although the separation of high performing African American students in honors classes forg- 
es social bonds with academically talented students from different racial and ethnic backgrounds, it also separates them from lower-performing students of color. This speaks to the loss of social and cultural capital among disadvantaged African Americans (Wilson 1987). If middle-class African American students are educated in separate classrooms and, in

\section{References}

Anyon, Jean. 2014. Radical Possibilities: Public Policy, Urban Education, and a New Social Movement. New York: Routledge.

Bifulco, Robert, Helen Ladd, and Stephen Ross. 2009. “Public School Choice and Integration: Evidence from Durham, North Carolina." Social Science Research 38:71-85.

Bodovski, Katerina. 2010. "Parental Practices and Educational Achievement: Social Class, Race, and Habitus." British Journal of the Sociology of Education 31(2):139-156.

Bourdieu, Pierre. 1984. Distinction. London: Routledge.

Bourdieu, Pierre and Jean-Claude Passeron. 1990. Reproduction in Education, Society, and Culture. London: Sage.

Bureau of the U.S. Census. 2017. State and County Quick Facts. Retrieved September 20, 2017 (https://www.census.gov/quickfacts/ fact/table/albanycitynewyork,albanycountynewyork/PST045216).

Campbell, Colin. 2009. "Distinguishing the Power of Agency from Agentic Power: A Note on Weber and the 'Black Box' of Personal Agency." Sociological Theory 27(4):407-418.

Capital District Regional Planning Commission. 2015a. "Median Household Incomes Flat and Income Inequality Still Exists." Retrieved July 01, 2017 (http://cdrpc.org/2018/01/median-household-incomes-slump/).

Capital District Regional Planning Commission. 2015b. “Community Fact Sheets." Retrieved May 03, 2017 (http://cdrpc.org/data/cfs/).

Carnoy, Martin et al. 2005. The Charter School Dust-Up: Examining the Evidence on Enrollment and Achievement. Washington: The Economic Policy Institute. turn, develop peer networks primarily with other, more disadvantaged students, the capital that poor and working-class African American students can accrue is substantially diminished. Research should continue to examine the institutional practices that uphold these stratified outcomes and seek out policies and programs that will reverse such forces.

Charmaz, Kathy. 2014. Constructing Grounded Theory. Los Angeles: Sage Publications.

City School District of Albany. 2017. Retrieved January 04, 2017 (http://www.albanyschools.org/schools/albanyhighschool/2013-14/ CoursebookFINAL.11-25-13.pdf).

Cohen, Patricia. 2020. "In Blue States and Red, Pandemic Upends Public Services and Jobs." The New York Times, December 04.

Coleman, James. 1988. "Social Capital in the Creation of Human Capital." The American Journal of Sociology 94:S95-S120.

Collins, James. 2009. "Social Reproduction in Classrooms and Schools." Annual Review of Anthropology 38:33-48.

Conley, Dalton. 1999. Being Black: Living in the Red: Race, Wealth, and Social Policy in America. Berkeley, CA: University of California Press.

Correia, Nicole. 2015. "How Albany Can Make Its Case Better for Why Young Families Should Stay." All Over Albany, October 28.

Crozier, Gill, Diane Reay, and David James. 2011. “Making it Work for Their Children: White Middle-Class Parents and Working Class Schools." International Studies in Sociology of Education 21(3):199-216.

Currie, Janet and Enrico Moretti. 2003. “Mother's Education and Intergenerational Transmission of Human Capital: Evidence from College Openings." The Quarterly Journal of Economics 118(4):1495-1532.

Davis, Tomeka M. and Adria N. Welcher. 2013. “School Quality and the Vulnerability of the Black Middle-Class: The Continu- 
ing Significance of Race as a Predictor of Disparate Schooling Environments." Sociological Perspectives 56(4):467-493.

Freeman, Lance. 2008. "Is Class Becoming a More Important Determinant of Neighborhood Attainment for African-Americans?" Urban Affairs Review 44(1):3-26.

Friedman, Samantha and Emily Rosenbaum. 2007. "Does Suburban Residence Mean Better Neighborhood Conditions for All Households? Assessing the Influence of Nativity Status and Race/Ethnicity." Social Science Research 36(1):1-27.

Gillborn, David et al. 2012. "You Got a Pass, So What More Do You Want? Race, Class, and Gender Intersections in the Educational Experience of the Black Middle Class." Race, Ethnicity, and Education 15(1):121-139.

Glaser, Barry and Anselm Straus. 1967. The Discovery of Grounded Theory: Strategies for Qualitative Research. Chicago: Aldine.

Gould, Deborah. 2009. Moving Politics: Emotion and ACT UP's Fight Against AIDS. Chicago: University of Chicago Press.

Grant, Gerald. 2009. Hope and Despair in the American City: Why There Are No Bad Schools in Raleigh. Cambridge: Harvard University Press.

Hardaway, Cecily and Vonnie McLoyd. 2009. “Escaping Poverty and Securing Middle Class Status: How Race and Socioeconomic Status Shape Mobility Prospects for African Americans During the Transition to Adulthood." Journal of Youth and Adolescence 38(2):242-256.

Hatch, J. Amos. 2002. Doing Qualitative Research in Education Settings. Albany, NY: State University of New York Press.

Haynes, Katherine, Kristie Phillips, and Ellen Goldring. 2010. "Latino Parents' Choice of Magnet Schools: How School Choice Differs Across Racial and Ethnic Boundaries." Education and Urban Society 42(6):758-789.

Henig, Jeffrey. 1996. "The Local Dynamics of Choice: Ethnic Preferences and Institutional Responses." Pp. 95-117 in Who Chooses? Who Loses? Culture, Institutions and the Unequal Effects of School Choice, edited by B. Fuller, R. Elmore, and G. Orfield. New York: Teachers College Press.

Horvat, Erin and Kristine Lewis. 2003. "The Importance of Peer Groups in Managing Academic Success." Sociology of Education 76(4):265-280.
Kozol, Jonathan. 1995. Amazing Grace: The Lives of Children and the Consciousness of the Nation. New York: Random House.

Krysan, Maria et al. 2009. "Does Race Matter in Neighborhood Preferences? Results from a Video Experiment."American Journal of Sociology 115(2):527-559.

Kuebler, Meghan. 2012. "Lending in the Modern Era: Does Racial Composition of Neighborhoods Matter when Individuals Seek Home Financing? A Pilot Study in New England." City $\mathcal{E}$ Community 11(1):31-50.

Lacy, Karyn. 2007. Blue-Chip Black: Race, Class, and Status in the New Black Middle Class. Berkeley, CA: University of California Press.

Lareau, Annette. 2003. Unequal Childhoods: Class, Race, and Family Life. Berkeley, CA: University of California Press.

Massey, Douglas and Nancy Denton. 1993. American Apartheid: Segregation and the Making of the Underclass. Cambridge, MA: Harvard University Press.

Montgomery, Alesia. 2006. “Living in Each Other's Pockets: The Navigation of Social Distances by Middle Class Families in Los Angeles." City E Community 5(4) December:425-450.

New York State Department of Education. 2017. Retrieved October 17, 2017 (https://data.nysed.gov/).

Patacchini, Eleonora and Yves Zenou. 2007. "Intergenerational Education Transmission: Neighborhood Quality and/or Parents' Involvement." Institute for the Study of Labor (IZA). February.

Pattillo, Mary. 2005. "Black Middle Class Neighborhoods." Annual Review of Sociology 31:305-329.

Pattillo, Mary. 2015. "Everyday Politics of School Choice in the Black Community." Du Bois Review 12(1):41-71.

Pattillo-McCoy, Mary. 1999. Black Picket Fences: Privilege and Peril Among the Black Middle Class. Chicago: University of Chicago Press.

Pattillo, Mary, Lori Delale-O'Connor, and Felicia Butts. 2014. "High-Stakes Choosing." Pp. 237-267 in Choosing Homes, Choosing Schools, edited by A. Lareau and K. Goyette. New York: Russell Sage Foundation.

Ravitch, Diane. 2014. Reign of Error: The Hoax of the Privatization Movement and the Danger to America's Public Schools. New York: First Vintage Books. 
Rhodes, Anna and Stefanie DeLuca. 2014. "Residential Mobility and School Choice among Poor Families." Pp. 137-166 in Choosing Homes, Choosing Schools, edited by A. Lareau and K. Goyette. New York: Russell Sage Foundation.

Sampson, Robert J. 2012. Great American City: Chicago and the Enduring Neighborhood Effect. Chicago: University of Chicago Press.

Sharkey, Patrick. 2013. Stuck in Place: Urban Neighborhoods and the End of Progress Toward Racial Equality. Chicago: University of Chicago Press.

Smrekar, Claire. 2009a. "The Social Context of Magnet Schools: How and Why Parents Choose Magnets." Pp. 393409 in Handbook of Research on School Choice, edited by M. Berends et al. Mahwah, NJ: Lawrence Erlbaum.

Smrekar, Clair. 2009b. "Beyond the Tipping Point: Issues of Racial Diversity in Magnet Schools Following Unitary Status." Peabody Journal of Education 84(2):209-226.

Spielauer, Martin. 2004. "Intergenerational Educational Transmission within Families: An Analysis and Microsimulation Projection for Austria." Vienna Yearbook of Population Research 2:253-282.

Stillman, Jennifer B. 2012. Gentrification and Schools: The Process of Integration when Whites Reverse Flight. New York: Palgrave MacMillan.

Stulberg, Lisa M. 2004. "What History Offers Progressive Choice Scholarship." Pp. 7-51 in The Emancipatory Promise of Charter Schools: Toward a Progressive Politics of School Choice, edited by E. Rofes and L. M. Stulberg. Albany: SUNY Press.
Swaroop, Sapna and Maria Krysan. 2011. "The Determinants of Neighborhood Satisfaction: Racial Proxy Revisited." Demography 48(3):1203-1229.

Torres, Kimberly and Douglas Massey. 2012. "Fitting In: Segregation, Social Class, and the Experiences of Black Students at Selective Colleges and Universities." Race and Social Problems 4(3-4):171-192.

U.S. Department of Health and Human Services. 2014. 2014 Poverty Guidelines. Retrieved May 12, 2014 (https://aspe.hhs.gov/2014-poverty-guidelines).

Vincent, Carol et al. 2012a. “Being Strategic, Being Watchful, Being Determined: Black Middle-Class Parents and Schooling." British Journal of Sociology of Education 33(3):337-354.

Vincent, Carol et al. 2012b. "Raising Middle Class Black Children: Parenting Priorities, Actions, and Strategies." Sociology 47(3):427-442.

Vincent, Carol et al. 2013. "Three Generations of Racism: Black Middle-Class Children and Schooling." British Journal of Sociology and Education 34(5-6):929-946.

Wells, Amy. 2009. "The Social Context of Magnet Schools: How and Why Parents Choose Magnets." Pp 155-178 in Handbook of Research on School Choice, edited by M. Berends et al. Mahwah, NJ: Lawrence Erlbaum.

Wells, Amy and Robert Crain. 1997. Stepping Over the Color-Line: African American Students in White Suburban Schools. New Haven: Yale University Press.

Wilson, William J. 1987. The Truly Disadvantaged: The Inner City, the Underclass, and Public Policy. Chicago: University of Chicago Press.

\section{Citation}

Knudson, Paul. 2021. "Continuing Social Constraints in Education Agency: The School Choices and Experiences of Middle-Class African American Families in Albany, NY." Qualitative Sociology Review 17(1):150-175. Retrieved Month, Year (http:// www.qualitativesociologyreview.org/ENG/archive_eng.php). DOI: http://dx.doi.org/10.18778/1733-8077.17.1.10 